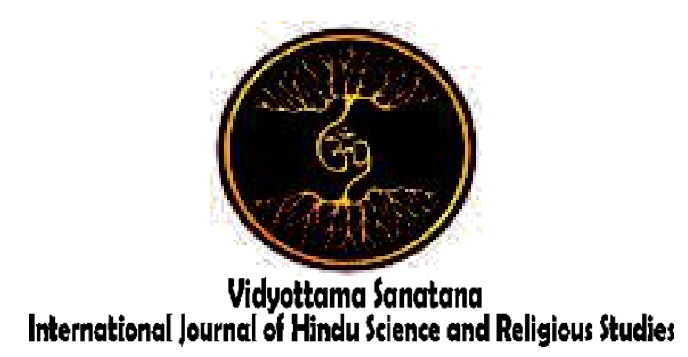

Vol. 3 No. 2 October 2019

\title{
THE EFFECTIVENESS OF FREE LAPTOP DISTRIBUTION FOR THE STUDENTS OF ELEMENTARY SCHOOL IN BADUNG REGENCY (CASE STUDY SD 6 DALUNG)
}

\author{
By:
}
I Putu Suyasa Ariputra, Ni Made Anggreni, I Ketut Wisarja, Kadek Aria Prima Dewi PF Institut Hindu Dharma Negeri Denpasar
E-mail : primadewipf@gmail.com

\begin{abstract}
Mastery of Science and Technology is one of the components to be achieved national education. Badung district government gives free laptop as much as 8,636 laptops for the students of elementary school. This free laptop distribution is borrowing to students to prepare human resources that not only the function as recipients of information flow but also equip themselves with information and technology management capabilities in order to be able to manage, adjust and develop what they receive through the development of these technologies. Looking at the conditions of technology mastery (laptop) as the access of information is not enough controlled by the teacher as an educator and employee as an educational staff but also learners (students).
\end{abstract}

Keywords: Technology, Government

\section{INTRODUCTION}

Humans are called as animal educanum and animal educandus which means humans as educated creatures and educating creatures. This indicates that humans are beings who struggle intensely with education. Human beings are very involved in the educational process both directly related to themselves and others. Education is defined as humanization (the effort to humanize humans), that is an effort in order to help humans (learners) in order to be able to live in accordance with the dignity of their humanity. 
Based on the above opinion, education as a process of humanizing human is that the process of education trying to make humans as fully human beings. Education basically has a function to awareness of human that they are able to know, understand and understand the reality of life which is there around them as well. With the education, human beings are expected to realize the potential that they have as a thinking creature. The potential referred to is the spiritual potential, soul, mind and body. By doing the human thinking process will find the existence of its presence as a creature that has been given the sense by God Almighty.

In the RI Law no. 20 of 2003 Chapter I Article 1 generally states education is a conscious and planned effort to create a learning atmosphere and learning process so that students can actively develop their own potential for the betterment of themselves, society, nation and country. National Education based on Pancasila and the 1945 Constitution, is the most important part in the development of human resources. National Education has a function to develop students' abilities optimally, forming good character until they can educate the life of nation.

In accordance with the education path in Indonesia that includes education that is informal, formal, and nonformal. The path of family and environmental education is called informal education. Educational paths that have a structure and tiered consisting of primary education (elementary school), middle (junior high school, senior high school), and also higher education, this is called formal education. Whereas non-formal education is an educational pathway outside formal education that can be implemented in a structured and tiered manner in the society. All three are considered able complement and enrich each other. This is in accordance with RI Law no. 20 Year 2003 Chapter VI Article 1 paragraph 1.

School as a formal institution is an institution to obtain the correct knowledge with the various components of learning that is in it. School is a sub-system of the sociocultural life system that becomes the second important educational institution after a family that is famous for formal education in order to shape the cognitive, affective and physichomotor of students. In line with this, education in schools aims to shape children in order to become human beings who have faith and piety to God Almighty and noble character, mastering science and technology, having skills, and being responsible and having an independent person in relation to social behavior that influence to the behavior will be independent or personal child concerned.

Mastery of Science and Technology is one of the components that want to achieved by national education. So much effort made by various parties in the achievement. Similarly, the government has a responsibility in the implementation of formal education. Rapid technological development for developing countries, building absorption capabilities through efforts learning, and adjusting existing technology to gain competitive advantage is the wisdom of mastering technology. One effective way of mastering technology is to introduce technology in education.

Education must be able to prepare human resources that not only serve as a recipient of information flow but also equip ourself information management capability and technology in order to be able manage, adjust and develop what it receives through the development of technologies. One of the effort that do by the government, especially the government of Badung regency for that matter is the distribution of free laptops for elementary and junior high school students.

Based on the news gathered by the Tribun Bali on Thursday, July 21, 2016 (14.51 WITA), the government of Badung Regency provides about 21 percent of the total local budget. Further Badung Regent I Nyoman Giri Prasta said that for education everything is free. To support the quality of education in Badung, the government of Badung district gives free laptop as many as 8,636 laptops to elementary school students. The distribution of free laptops is borrowing to students, when students terbut so the 
laptop returned to the school concerned. I Ketut Widya Astika convey the distribution of free laptop has several obstacles, one of them human resources, especially teachers who still can not operate the laptop. One of school whose students get a free laptop is SD 6 Dalung.

Geographically SD 6 Dalung is one of the schools located in Dalung, especially in Br. Campuan Asri, BTN. Dalung Permai, North Kuta District, Badung Regency, Bali Province. In accordance with the geographical location that is in urban and the conditions of society that heterogen so the use of technology also has been developed as well in this area. Based on that it is very interesting to see the effectiveness of free laptop distribution for elementary school students in Badung regency (Case Study of SD 6 Dalung).

\section{RESULT AND DISCUSSION 2.1 Overview of SD 6 Dalung}

Geographically SD 6 Dalung is one of the schools located in Dalung, especially in Br. Campuan Asri, BTN. Dalung Permai, District of North Kuta, Badung Regency, Bali Province. This elementary school is located in the middle of Dalung Permai housing which is one of the largest housing in Bali. The boundary area of SD 6 Dalung, Distric North Kuta is as follows. The north is bordered by the road of Bhineka Nusa Kauh. East border with Campuan Asri. The South is bordered by Campuan Asri. The west is bordered by the river Lingga Bumi.

Based on the data that obtained about the history of founding SD 6 Dalung as a result of population growth accompanied by urbanization from village to city, the Badung Regency government built residential population housing, including Cemara Giri Housing, Griya Tansa Trisna, Cepaka Mas Housing, Housing Dalung Sari, Dam Indah Housing, Housing Pengilian Permai, and others. The largest residential population built in Dalung area is Bumi Dalung Permai Housing which consists of approximately 6000 housing units. Bumi Dalung Permai Housing is designed as a Denpasar satellite city. SD 6 Dalung was built right in the middle of Bumi Dalung Permai housing as part of public facilities provided by developer. SD 6 Dalung was established in 2002 in 2 stages, the first stage was 1 unit consisting of 6 local (rooms) and the second stage was established in 2004 consisting of 4 local (rooms). So the total local or existing room is 10 rooms. Of the 10 existing rooms, 9 rooms are used for classrooms and 1 room is used for office (Principal room and Teacher room). Because the existence of SD 6 Dalung was established in the middle of very densely populated housing, so the number of students who must be accommodated since start from the first grade must be parallel to three.

Learners are very important elements that very important in school. The number of primary school students 6 Dalung quite a lot because this school includes a popular school. The condition of the learners is quite a lot and quality reflects the condition of successful schools in carrying out the learning process and achieve institutional goals. for the year 2017/2018 SD 6 Dalung has 18 study rombels with each in each grade level there are three learning Rombe. The students of class 1 numbered 117 people with details of 64 men and 53 women, class II numbered 109 people consisting of 55 men and 54 women, class III numbered 139 people with a numbered of men 72 people and the numbered of women is 67 people, class IV is 117 people consisting of 63 men and 54 women, class $\mathrm{V}$ is 123 people with details of 57 men and 66 women, class VI numbered 113 people with details of 61 men and 52 women.

Teachers or educators in Elementary School 6 Dalung as many as 30 people including the headmaster. While there are 7 employees. Teachers or educators of elementary school 6 Dalung have been trying to held an increase the quality of themself as educators with learning both formally and nonformally. Formally Teachers of elementary School 6 Dalung have been given the opportunity to study in universities either Diploma, S1, S2 in a non-formal manner. 
elementary school teachers or educators 6 Dalung attend upgrading and counseling in accordance with their respective fields of expertise. To find out the situation of teachers and employees of Primary School 6 Dalung can be seen in the following table. Most of the existing teaching staff are permanent teachers and have an undergraduate degree from all teachers which can be said that Dalung 6 elementary schools have enough teachers in terms of numbers if adjusted to the number of available learning groups.

\subsection{Use of Laptop For Grade V and VI Students at SD 6 Dalung}

Enactment of Law Number 22 Year 1999 concerning Sharia Regional Autonomy for the development of an area in a conducive and democratic atmosphere. In line with this [2] confirms that the autonomy imposed by the government also has an impact on decentralization in the world of Indonesian education. Local governments have the freedom to develop education maximally in each region by sticking to the central government rules. Also affirmed with Article 45 paragraph (1) Chapter XII related Facilities and Infrastructure, Law no. 20 of 2003 concerning SIDIKNAS generally states that each formal and non-formal education unit provides facilities and infrastructure that meet educational needs according to the needs of learners. So that the procurement of free laptops initiated by the Badung Regency government for grade V and VI elementary school students is an attempt by the regional government to develop the potential of students in mastering technology for the advancement of national education.

Laptops are personal computers that are rather small so that they can be carried and placed in the lap of their users, consisting of devices that include keyboards, display screens, microprocessors, and batteries. With the advancement of computer simplification technology into portable computers, information processing and information access are very easy to do. The ease and advancement of these technologies also affect the education world. Any information that is very easy and fast to access can be utilized in teaching and learning activities. So that the learning process takes place with rich information and interesting as a positive impact of technological progress. Based on this, the ability of human resources in mastering technology, especially in this case the laptop needs to be increased.

The use of computers or portable computer (laptops) in educational institutions cannot be denied their use even today has made needs that cannot be separated in other words is very necessary. Its use is not limited to information management activities in the completeness of educational administration alone, but in the implementation of learnig in the classroom. It is as a form of professionalism of educators and education personnel. In line with opinions [4] the professionalism of an educator and education staff is not enough with formal qualifications obtained from the place he graduated, but also must include four competencies, namely: 1) Pedagogic Competence; 2) Personal Competence; 3) Professional Competence; and 4) Social Competence. In accordance with professional competence, the teacher has the task to direct student learning activities to achieve predetermined goals, for that the teacher is required to be able to convey the learning material and the teacher must update and master the subject matter. So the mastery of technology has become an absolute thing for educators.

The ability to master technology well which is demanded for all Educators and education personnel for the smooth process of education is not enough. In the $21 \mathrm{st}$ century in the current era of globalization, people are faced with the fact that a variety of information is very free and open, the flow of information is channeled through various media that are obtained easily and quickly. Looking at the conditions of technology mastery (laptop) as the access to information is not sufficiently controlled by the teacher as an educator and employee as an educational staff but also the learners (students). 
The most popular learning approach is Student Centered Learning (SCL). SCL is a learning approach that emphasizes students as an active actors in learning. This learning is student-centered, students are more active in finding and exploring information related to the material being studied. The old paradigm that mentions that teachers are a single source of learning, now it's not relevant. With a new learning approach that is student-centered, it is undeniable that students must also be able to master technology. Because in this approach students are expected to be able to change themselves (behavior, ways of thinking and behaving) more effectively and efficiently.

SD 6 Dalung as one of the public elementary schools that in fact there is in urban areas with residents who have higher intensity of use of sophisticated technology tools, demanding schools to be ready to provide competencies that are in accordance with the needs of the society. Moreover with the heterogeneous circumstances of the school society making information very quickly accessible and growing. So it is very necessary to see how schools utilize existing facilities and infrastructure to meet the demands of the society.

Based on the results of the interview, Wayan Suyasa (May 11, 2018) who is the guardian of class VI A class conveyed that technological progress in this era cannot be stopped. Everything is now based on electronics. Even books are already electronic. But on implementation in the field to process the information administrative completeness of education is already more computer-based while in the learning activities in the classroom more often by manual. Laptops provided by the government are sometimes taken by students and used, but the nature is more only at the initial level of introduction. For further use such as making tasks with laptops has not been done. This is because the student's time is minimal with a lot of material. Moreover, sixth grade students need more repetition of the material. Considering the sixth grade students will face the Exams. So that students are given more material related to the subjects being tested.

The same opinion was also conveyed by I Gusti Ayu Made Supartini (May 11, 2018) as the guardian of class VI C, laptops and smartphones are currently two electronic goods that as the current needs. Both of these objects are not only owned by parents but the children are already adept at operating them even more smartphones. The sting children quickly understand how to operate it, but this progress also brings negative impacts such as the inability of children to use the smartphone. As for the use of laptops in schools, it is more directed that students access information on subject matter. It is also very limited given the number of effective days in a semester on a limited educational calendar with the amount of material to be completed. Moreover, the sixth grade is more likely to carry out the consolidation of the final exam preparation. So that the usage also looks at the situation, if there is an empty time then the laptop operation training can be done at that time.

While the guardian of class V B (I Ketut Wardana, May 11, 2018) explained that free division of laptops for elementary students, especially class $\mathrm{V}$ is a good program. This program makes it easy for schools to guide children to actively seek information by electronic media, for example, to find information related parts of the human body and the picture and then pasted on a notebook. So the children are easier to remember. In addition, for class V students, increasing the ability to operate laptops is more often done during computer extracurricular activities. During extracurricular activities, students are given basic methods of operating MS.Word. He also added that the government should provide training to teachers especially in operating the laptop in order not to become technological stutter, especially given the training related to existing applications in the laptop because there are some laptops in the application is not running properly. So that the training provided to the teacher can later help students more effectively. 
According to Made Dharma Sedana Putra (May 11, 2018) grade 5 students said that the laptop can be taken occasionally to school and taught to operate it. But the intensity of its use is very rare even once a month is not necessarily brought to school. Meanwhile, if at home he more often operate a smartphone than a laptop that is given. This is because the family is not too able to operate the laptop. So it is easier to use a smartphone to access information.

Based on the above interviews both from the point of view of educators and students, the intensity of the use of laptops provided by the government of Badung Regency is still low. This is due to several things: the use of laptops during the teaching and learning process spent more time so that the material can be delivered very little, the number of students with a lot of teachers as a tutor to make teachers difficult to monitor students, inadequate human resources who can operate it expertly.

\section{CONCLUSION}

In the 21 st century in the current era of globalization, people are faced with the fact that a variety of information is very free and open, the flow of information is channeled through various media that are obtained easily and quickly. Glance at the condition, mastery of technology (laptop) as access to information is not sufficiently controlled by the teacher as an educator and employee as an educational staff but also students (students). Moreover, the change of paradigm approach of learning from Teacher centered now becomes Student Centered Learning (SCL). SCL is a learning approach that emphasizes students as active actors in learning. In order to improve the quality of education the Badung Regency government initiated a program to provide free laptops for elementary students in Badung Regency. Based on interviews in SD 6 Dalung found several obstacles, namely: the use of laptops during the teaching and learning process more time spent so that the material can be delivered very little, the large number of students with one teacher as a tutor makes it difficult for teachers to monitor students, inadequate human resources can operate it expertly.

\section{REFERENCES}

Chan, M. S., \& Sam, T. T. (2005). ANALISIS SWAOT: Kebijakan Pendidikan Era Otonomi Daerah. Jakarta: Raja Grafindo.

Dantes, Nyoman. 2014. Landasan Pendidikan. Yogyakarta: Graha Ilmu.

Rohani, A. (2010). Pengelola Pengajaran. Jakarta: PT Rineka Cipta.

Rusman. (2010). Metode Belajar. Jakarta: Rajawali.

Sanjaya, Wina. 2008. Strategi Pembelajaran: Berbasis Standar Proses Pendidikan. Jakarta: Kencana Prenada Media Group.

Sukardjo, M., \& Kommarudin, U. (2012). Landasan Pendidikan. Jakarta: Rajawali Press.

Tim Penyusun Dapertemen Pendidikan Nasional. (2007). Undang-Undang Republik Indonesia Nomor 20 SIDIKNAS (Sistem Pendidikan Nasional). Jakarta: Sinar Grafika. Wahyudin. (2009). Pengantar Pendidikan. Jakarta: Universitas Terbuka. 